\title{
SENSORY PROPERTY AND Benzo(a)Pyrene (Bap) LEVEL IN SE'I PROCESSED FROM CULL BALI COW BEEF
}

\author{
Gemini E.M. Malelak ${ }^{1),}$, Maria R. Deno Ratu ${ }^{1)}$, Gusti A. Y. Lestari ${ }^{1)}$, Imanuel Benu ${ }^{1)}$, I Gusti N. Jelantik ${ }^{1)}$ \\ 1) Faculty of Animal Science, Nusa Cendana University, Jl. Adi Sucipto Penfui No.85001, Lasiana, Klp. Lima, \\ Kota Kupang, Nusa Tenggara Timur. Indonesia, 85001 \\ *Email: geminimalelak@staf.undana.ac.id \\ Submitted 17 February 2020; Accepted 11 June 2020
}

\begin{abstract}
The objectives of this experiment were to evaluate the effect of using meat obtained from cull Bali cows differing in body condition score (BCS) on sensory property and benzo(a)pyrene (BaP) level on se'i (Rotenesse smoked beef). A completely randomized design 9x3 was used in this experiment. The nine treatments were BCS 2 with open smoking method (BCS2O), BCS 2 with close smoking method (BCS2C), BCS 2 given liquid smoke (BCS2LS), BCS 3 with open smoking method (BCS3O), BCS 3 with close smoking method (BCS3C), BCS 3 given liquid smoke (BCS3LS), BCS 4 with open smoking method (BCS4O), BCS 4 with close smoking method (BCS4C), and BCS 4 given liquid smoke (BCS4LS). Parameter measured were sensory property and benzo(a)pyrene (bap) content of se'i. The data of sensory property were analyzed using Kruskal-Wallis test followed by Mann-Whitney test. The data of benzo(a)pyrene (BaP) content was analysed using analysis of variance followed by Duncant test. Results showed that se'i produced from group BCS4LS possessed higher score on taste and tenderness, whereas the strongest aroma of se'i was found in se'i processed by both open and close smoking method in all BCS group. The highest benzo(a)pyrene content $(0.0052$ $-0.0055 \mathrm{ppm}$ ) was found in se'i processed by close smoking method in all BCS group, followed by se'i was added liquid smoke in all BCS group. It is suggested that meat of cull Bali cows with BCS4LS could be used to produce se'i with preferable taste,n tenderness and could lower the accumulation of $\mathrm{BaP}$ in se'i.
\end{abstract}

Key words: Benzo(a)pyrene; body condition score; sensory quality; smoking method 


\section{INTRODUCTION}

Se'i is a traditional smoked beef from East Nusa Tenggara (NTT) which, as many other smoked beef, is strongly influenced by the quality of fresh meat. Low quality se'i found in local market is often due to the fact that meat used predominantly comes from thin cull Bali cows. Higher quality of se'i can be produced from cull cows of higher body condition score of fattened cull Bali cows which have higher body condition score (BCS) at slaughter.

These cows not only produce higher quantity of meat but also of higher quality (Jelantik et al., 2014). Body condition directly affect body composition, i.e. water, protein, fat and mineral content (Otto et al., 1991; Whitter et al., 1993) which are known as the determinant factors controlling meat texture (Guzek et al., 2013) which is one of dominant factor affecting the quality differences in processed meat.

The ultimate quality of se'i, however, is also highly depending upon the smoking technique applied. During smoking process, heat is transferred, and different chemical fractions are deliberately produced. In addition, different heating rate affects drying rate which has bactericidal consequences. Similarly, different substances are liberated during smoking have bacteriostatic and bactericidal effect which suppress bacterial growth during preservation.

Heating and smoking also contribute to aroma, flavor and color development of se'i. Other substances, however, have negative effect on smoked beef or even harmful for human health. As a result of incomplete burning, organic matter of wood produces polycyclic aromatic hydrocarbon (Rey-Salgueiro et al., 2008), e.g.

*Corresponding author:

Gemini E.M. Malelak

Email: geminimalelak@staf.undana.ac.id

Faculty of Animal Science, Nusa Cendana

University, Jl. Adi Sucipto Penfui No.85001,

Lasiana, Klp. Lima, Kota Kupang, Nusa Tenggara

Tim. Indonesia, 85001 benzo(a)pyrene (BaP) (Ramalhosa et al., 2009) which has been known to possess carsinogenic, mutagenik, lypophilic and bioaccumulative effects.

Therefore, it is possible that different smoking techniques, i.e. open traditional smoking technique will differ in those aspects compared to close smoking technique as well as to smoking with liquid smoke. The differences are also possibly dependent upon the quality of fresh meat from different BCS of cull Bali cows. Therefore, the objectives of this experiment were to investigate the sensory properties and benzo(a)pyrene (BaP) level of se'i (Rotenese smoked beef) made of fresh meat from different BCS cull Bali cows then smoke in different techniques.

\section{MATERIALS AND METHODS}

\section{Experimental design}

A $9 \times 3$ completely randomized design (CRD) was used in this study. The nine treatments were BCS 2 with open smoking method (BCS2O), BCS 2 with close smoking method (BCS2C), BCS 2 given liquid smoke (BCS2LS), BCS 3 with open smoking method (BCS3O), BCS 3 with close smoking method (BCS3C), BCS 3 given liquid smoke (BCS3LS), BCS 4 with open smoking method (BCS4O), BCS 4 with close smoking method (BCS4C), and BCS 4 given liquid smoke (BCS4LS).

\section{Se'i processing}

Fresh meat (i.e. Bicep femoris) from cull cows having body condition score of 2 , 3 and 4 (according to 5 scoring system) was obtained from Kupang slaughterhouse. Meat was separated from fat before being sliced into rope shape. The sliced meat was then added $2 \%(\mathrm{w} / \mathrm{w})$ salt $(\mathrm{NaCl})$ and saltpeter

How to cite:

Malelak, G. E. M., Ratu, M. R. D., Lestari, G. A.Y., Benu, I., \& Jelantik, I. G. N. (2020). Sensory Property and Benzo(a)Pyrene (Bap) Level in Se'i Processed from Cull Bali Cow Beef. Jurnal Ilmu dan Teknologi Hasil Ternak, 15 (2), 78-85 
$\left(\mathrm{KNO}_{3}\right) 300 \mathrm{mg}$ per $\mathrm{kg}$ meat. The saltpeter was diluted in $2 \mathrm{~mL}$ water before being added to the meat. Meat from each different BCS was divided into three to be smoked with three different techniques, i.e. open $(\mathrm{O})$, close $(\mathrm{C})$ or injected with $1 \%(\mathrm{v} / \mathrm{w})$ kusambi (Schleichera oleosa) liquid smoke (LS). All meat was cured for $12 \mathrm{~h}$ and smoked for $\pm 45 \mathrm{~min}$. When the smoking was done, se'i was let to rest and samples were thereafter taken from each treatment for sensory evaluation and $\mathrm{BaP}$ content analysis.

\section{Sensory evaluation and benzo(a)pyrene (BaP) content analysis}

A twenty-five 25 untrained panelists from Animal Science Faculty of Nusa Cendana University involved in sensory evaluation. Hedonic scale was used for each sensory characteristic including aroma, taste and tenderness. For the aroma test, three $30 \mathrm{~g}$ cuts from each treatment were put into glass beaker and close tightly for $30 \mathrm{~min}$. Panelist were asked to inhale and score using 5 scaling system (Bensink et al., 1973) according to the criterion presented in Table 1. For taste and tenderness, three cuts ( $2 \times 1 \mathrm{~cm}$ and $3 \mathrm{~mm}$ thick) for each treatment were placed on white plate. Panels were then asked to give hedonic score according to criterion presented in Table 1. Benzo(a)pyrene $(\mathrm{BaP})$ content was analyzed following the procedure of Cho dan Shin (2012).

A $5 \mathrm{~g}$ sample was blended and mounted into extraction flask and extracted using $5 \mu \mathrm{g} / \mathrm{kg}$ 3-methylcholanthrene, and further saponified using $1 \mathrm{M} \mathrm{KOH}$ in ethanol at $80^{\circ} \mathrm{C}$ to isolate $\mathrm{BaP}$. After cooling down, the samples were removed into 300-mL funnel separated using a mixture of $50 \mathrm{~mL}$ ethanol- $n$-hexane $(1: 1)$ and $n$ hexane. The residues were then extracted twice using $50 \mathrm{~mL} n$-hexane and washed three times using $50 \mathrm{~mL}$ distilled water before being dried using $\mathrm{Na}_{2} \mathrm{SO}_{4}$ and concentrated using low pressure rotary evaporator until the aliquot became $2 \mathrm{~mL}$ at $35^{\circ} \mathrm{C}$.

\section{Statistical Analysis}

Sensory evaluation data, i.e. aroma, taste and tenderness, were analyzed using Kruskall-Wallis test followed by MannWhitney test. Meanwhile, the data of benzo(a)pyrene (BaP) content were analyzed using analysis of variance followed by Duncan test (SPSS 20).

\section{RESULTS AND DISSCUSION}

\section{Sensory property of se'i}

Aroma. The aroma of se'i when smoked with liquid smoke produced inferior aroma in all BCS compared to other smoking techniques. This was possibly due to the infiltration of liquid smoke into meat during curing thereby tissue structures became loosen which further stimulated higher loss of volatile compounds and fat through evaporation and drip during smoking. The excessive drip of fat with application of liquid smoke caused se'i to lose its aroma. Rabe et al. (2003) reported that fat is mostly responsible in producing aroma.

Fat tissue produce volatile components such as acids, alcohols, aldehydes and ketones (Mottram, 1998).The lowest aroma score was shown in se'i made from meat of cull Bali cows with BCS4. Those differences were mainly caused by the difference in moisture, protein and fat content of fresh meat from cows differing in BCS. The content of water, protein and fat in fresh meat in BCS 2 was; $62.25 \%$; $28.62 \%$, and $6.42 \%$ respectively. In BCS 3 was; $65.36 \% ; 25.59 \%$, and $7.05 \%$, respectively.

In BCS 4 was; $67.12 \% ; 21.03 \%$, and $8.96 \%$, respectively. In general, aroma is detected by the olfaction organs through stimulation from different water-soluble compounds such as free amino acids and substances related to ATP (Ichimura et al., 2017). However, Kinsella (1990) demonstrated that aroma was more affected by fat rather than water-soluble compounds. The result of this experiment was unexpected as meat from cull Bali cows with 
BCS4 contained higher moisture $(67.12 \%)$ and fat content $(8.96 \%)$ compared to BCS3 $(65.36 \%$ of moisture and $7.05 \%$ of fat $)$ and
BCS2 $(62.25 \%$ of moisture and $6.42 \%$ of fat) which should have produce se'i with highest aroma score.

Table1. Hedonic sore for organoleptic test

\begin{tabular}{ccc}
\hline Variable & Hedonic scale & Criterion \\
\hline Aroma & 5 & extremely like \\
& 4 & like \\
& 3 & neutral \\
& 2 & dislike \\
& 1 & extemely dislike \\
\hline Taste & 5 & extemely like \\
& 4 & like \\
& 3 & neutral \\
& 2 & dislike \\
& 1 & extemely dislike \\
\hline Tenderness & 5 & extemely tender \\
& 4 & tender \\
& 3 & though \\
& 2 & extremely though \\
\hline
\end{tabular}

Table 2. Average score of aroma, taste and tenderness of se'i made from fresh meat of cull Bali cows smoked with different techniques

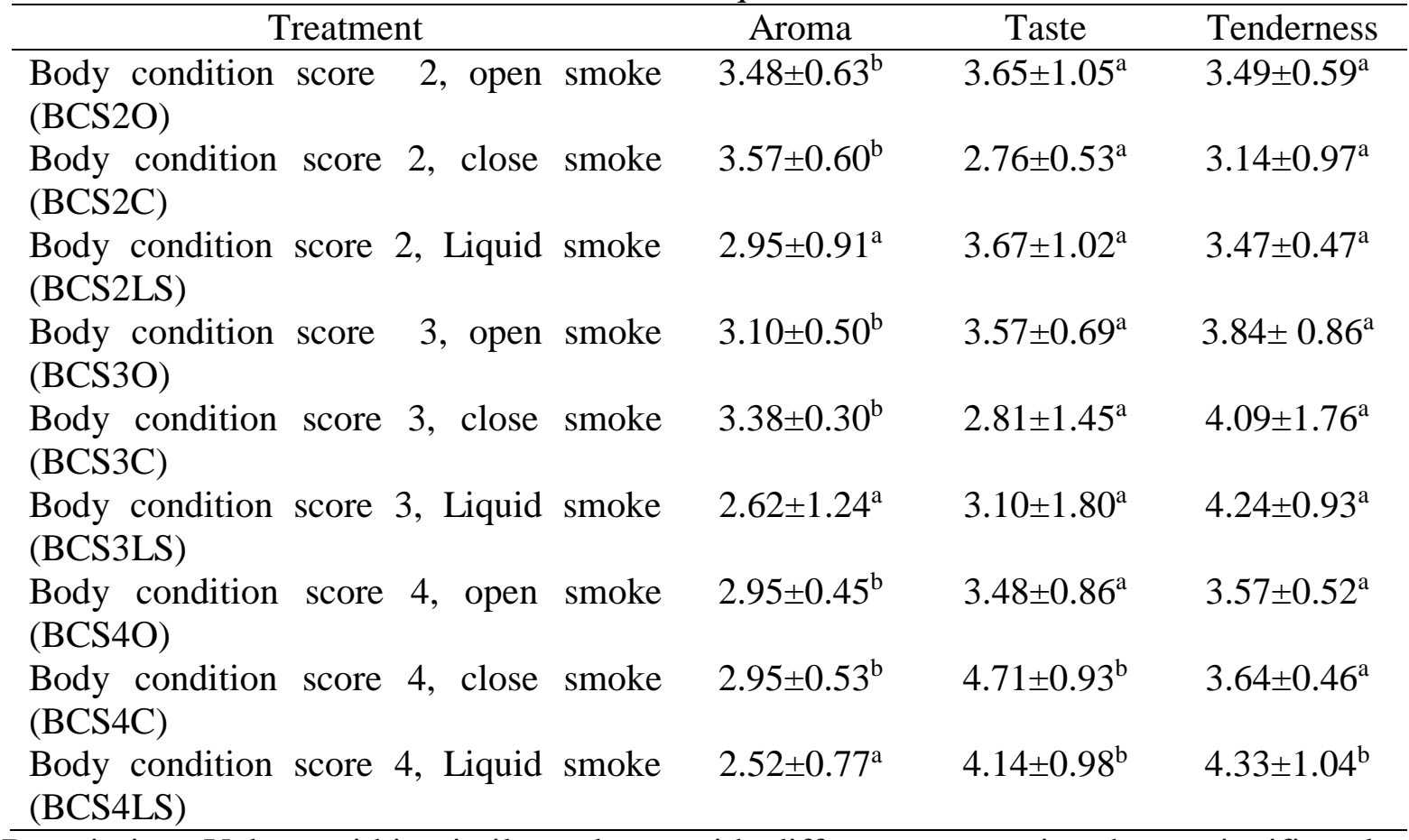

Description: Values within similar column with different superscript shows significantly different $(\mathrm{P}<0.05)$

One possible reason for this discrepancy is that in smoked beef, aroma is also stimulated by phenolic compounds found in the smoke. During smoking, phenolic compounds are attached to meat surface and thereafter infiltrates into meat tissue to form hydrogen chains between hydroxyl groups and collagen (Daun, 1979). 
However, some phenolic compounds are readily absorbed by fat compared to water (Doerr dan Fiddler, 1970; Issenberg et al., 1971), and during smoking process, fat melted.

Therefore, the low aroma for se'i from BCS 4 was apparently due to the excessive loss of fat during smoking. This was indicated by fat content of se'i, which was comparable among different BCS, regardless higher fat content of fresh meat of cows with BCS 4. Results showed that highest score for taste was for meat from cull cows BCS 4 with close smoking (BCS4C)and liquid smoke (BCS4LS). This finding could be explained by the higher content of fat in BCS 4 and less fat loss with close smoking and the application of liquid smoke.

Fat is the predominant source of specific flavor (aroma and taste) in meat (Anandh and Lakshmanan, 2014) both in fresh meat (Wood and Enser, 1997; Calkins and Hodgen, 2007) or phospholipid in cooked meat (Gandemer, 1997). This finding is understandable as taste is determined by many components of meat such as the content of water-soluble components, nitrogenous compounds and variety of minerals contained in sarcoplasm (Ichimura et al., 2017). Similarly, Nishimura et al. (1998) reported that non protein compounds are also responsible to stimulate taste. However, the most important taste precursor is fat content. Therefore, it is expected that se' $i$ from BCS 4 was tastier than others as it contained higher fat and more of other components.

As shown in Table 2 the highest score was shown in se'i made of BCS 4 treated with liquid smoke (BCS4LS). This appeared to be due to the higher fat content of meat from cows with BCS 4 compared to thinner cows (BCS 2 and BCS 3). Many factors are known to affect meat tenderness including genetic (Lian et al., 2013), the amount of connected tissue and protein structure (Jukna et al., 2008; 2010), collagen content (Nishimura, 2015), and particularly the degree of fatness (Ustener, 2017). In addition, heating temperature (Lepetit, 2008) and heating method (Munchene et al., 2009) also determine meat tenderness. In the present study, it seems that liquid smoke which was injected into the meat during curing helped to loosen meat fiber and during smoking fat was melted and enter the meat fiber to replace water.

Table 3. Benzo(a)pyrene content of se'i

\begin{tabular}{lc}
\hline \multicolumn{1}{c}{ Treatment } & $\begin{array}{c}\text { Benzo(a)pyrene content } \\
(\mathrm{ppm})\end{array}$ \\
\hline Body condition score 2, open smoke (BCS2O) & $0.0019 \pm 0.01^{\mathrm{a}}$ \\
Body condition score 2, close smoke (BCS2C) & $0.0053 \pm 0.02^{\mathrm{c}}$ \\
Body condition score 2, Liquid smoke (BCS2LS) & $0.0026 \pm 0.01^{\mathrm{b}}$ \\
Body condition score 3, open smoke (BCS3O) & $0.0019 \pm 0.01^{\mathrm{a}}$ \\
Body condition score 3, close smoke (BCS3C) & $0.0055 \pm 0.01^{\mathrm{c}}$ \\
Body condition score 3, Liquid smoke (BCS3LS) & $0.0030 \pm 0.02^{\mathrm{b}}$ \\
Body condition score 4, open smoke (BCS4O) & $0.0017 \pm 0.01^{\mathrm{a}}$ \\
Body condition score 4, close smoke (BCS4C) & $0.0052 \pm 0.01^{\mathrm{c}}$ \\
Body condition score 4, Liquid smoke (BCS4LS) & $0.0030 \pm 0.02^{\mathrm{b}}$ \\
\hline
\end{tabular}

\section{$\operatorname{Benzo}(a)$ pyrene content}

The differences in the level of benzo(a)pyrene $(\mathrm{BaP})$ in se'i are presented in Table 3. BaP content was significantly higher $(\mathrm{P}<0.05)$ in se'i which was made by close smoking technique. This result was in line with the result reported by Ghazali et al.
(2014) when they found that smoking manyung fish (Arius thalassinus) by close system resulted in higher $\mathrm{BaP}(0.0078 \mathrm{ppm})$ compared to using liquid smoke (0.0041 ppm). Similarly, Lukitaningsih et al. (2001) also recorded higher polycyclic aromatic hydrocarbons (PHA) in traditional 
smoked meat was $0.041 \mathrm{ppm}$ which was higher than meat which was given liquid smoke (0.00103-0.00926 ppm). BaP is produced during smoking when fatty acids pyrolysis occurs and attached to the surface of smoked products (Gomaa et al., 1993).

In the present study, the lower content of $\mathrm{BaP}$ in open smoking technique was probably due to less possibility of the smoke to attach to the meat surface. This also occurred with liquid smoke as meat was indirectly smoked. In addition, the BaP content of liquid smoke used in the present experiment was $0.0015 \mathrm{ppm}$ which is lower than $2 \mu \mathrm{g} / \mathrm{kg}$ as reported by Joint FAO/WHO Expert Committee on Food Additives (2001).

Nevertheless, all smoking technique produced se'i with $\mathrm{BaP}$ content close to the maximal level of $5 \mathrm{ppb}$ or $0.005 \mathrm{ppm}$ to be allowed in smoked beef (BPOM, 2009). This would be of concern since $\mathrm{BaP}$ is carcinogenic and one who smoke beef with close smoking technique to be causative.

\section{CONCLUSION}

Se'i made from meat of cull Bali cows with BCS 4 and added liquid smoke produce se'i with the best sensory quality while se'i made from meat of cull Bali cows with BCS 2, 3 and 4 and smoked in open method (BCS2O, BCS3O and BCS4O) contains the lowest level of benzo(a)pyrene.

\section{ACKNOWLEDGMENT}

Authors thank to the KemenristekDIKTI for funding support through "Penelitian Terapan Unggulan Perguruan Tinggi" in the year of 2019.

\section{REFERENCES}

Anandh, M. A., \& Lakshmanan, V. (2014). Storage stability of smoked buffalo rumen meat product treated with ginger extract. Journal of Food Science and Technology, 51(6), 1191-
1196. https://doi.org/10.1007/s13197012-0622-2

Badan Pengawas Obat dan Makanan Republik Indonesia. (2009a). Peraturan Kepala Badan Pengawas Obat Dan Makanan Republik Indonesia. Nomor HK.00.06.1.52.4011.

Badan Pengawas Obat dan Makanan Republik Indonesia. (2009b). Peraturan Kepala Badan Pengawas Obat Dan Makanan Republik Indonesia Nomor HK.00.06.1.52.4011.

Bensink, J. C., Ford, A. L., \& Yates, J. R. (1973). Properties and performance of a range of commercial, vacuum packaging films used for packing chilled beef. Meat Research Report, 4(1).

Calkins, C. R., \& Hodgen, J. M. (2007). A fresh look at meat flavor. Meat Science, 77(1), 63-80. https://doi.org/ 10.1016/j.meatsci.2007.04.016

Cho, H.-K., \& Shin, H.-S. (2012). Analysis of benzo[a]pyrene content from smoked food products in Korea. Food Science and Biotechnology, 21(4), 1095-1100. https://doi.org/10.1007/s 10068-012-0142-x

Daun, H. (1979). Interaction of wood smoke components and food. Technol, 33(5), 66-83.

Doerr, R. C., \& Fiddler, W. (1970). Partition ratios of some wood smoke phenols in two oil: water systems. Journal of Agricultural and Food Chemistry, 18(5), 937-939. https://doi.org/10.10 21/jf60171a046

Food and Drug Supervisory, R. of I. (2009). Regulation of Head of The Republic of Indonesia Food and Drug Supervisory Agency Nomor HK.00.06.1.52.4011. 
Gandemer, G. (1997). Phospholipides, lipolyse, oxydation et flaveur des produits carne's. $O C L, 4,1-7$.

Ghazali, R., Swastawati, F., \& Romadhon, R. (2014). Analisa tingkat keamanan ikan manyung (Arius thalassinus) asap yang diolah dengan metode pengasapan berbeda. Jurnal Pengolahan Dan Bioteknologi Hasil Perikanan, 3(4), 31-38.

Gomaa, E. A., Gray, J. I., Rabie, S., LopezBote, C., \& Booren, A. M. (1993). Polycyclic aromatic hydrocarbons in smoked food products and commerical liquid smoke flavourings. Food Additives and Contaminants, 10(5), 503-521. https://doi.org/10.10 $80 / 02652039309374174$

Guzek, D., Głąbska, D., Pogorzelska, E., Pogorzelski, G., \& Wierzbicka, A. (2013). Instrumental texture measurement of meat in a laboratory research and on a production line. Advances in Science and TechnologyResearch Journal, 7(19), 5-11. https:// doi.org/10.5604/20804075.1062329

Ichimura, S., Nakamura, Y., Yoshida, Y., \& Hattori, A. (2017). Hypoxanthine enhances the cured meat taste. Animal Science Journal, 88(2), 379-385. https://doi.org/10.1111/asj.12625

Issenberg, P., Kornreich, M. R., \& Lustre, A. O. (1971). Recovery of phenolic wood smoke components from smoked foods and model systems. Journal of Food Science, 36(1), 107-109. https:// doi.org/10.1111/j.1365-2621.1971.tb 02048.x

Jelantik, I. G., Malelak, G. E., Denoratu, M., \& Leo-Penu, C. (2014). Factors affecting the fattening efficiency of cull Bali cow offered local complete feed. The Asian-Australasian Association of Animal Production Societies.
Jukna, Č., Jukna, V., Pečiulaitiene, N., \& Klementavičiute, J. (2008). Postmortem changes in bovine muscle electrical conductivity \& its relationship to meat quality attributes. Veterinarija $\mathrm{Ir}$ Zootechnika, 41(63), 60-63.

Jukna, V., Jukna, Ç., Peçiulaitiene, N., Riškeviçiene, V., \& Korsukovas, A. (2010). Effect of genotype on growth intensity and meat quality of bulls. Veterinarija Ir Zootechnika, 50(72), 23-27.

Kinsella, J. E., Broughton, K. S., \& Whelan, J. W. (1990). Dietary unsaturated fatty acids: interactions and possible needs in relation to eicosanoid synthesis. The Journal of Nutritional Biochemistry, 1(3), 123-141. https://doi.org/10.1016 /0955-2863(90)90011-9

Lepetit, J. (2008). Collagen contribution to meat toughness: Theoretical aspects. Meat Science, 80(4), 960-967. https:// doi.org/10.1016/j.meatsci.2008.06.016

Lian, T., Wang, L., \& Liu, Y. (2013). A new insight into the role of calpains in postmortem meat tenderization in domestic animals: a review. Asian-Australasian Journal of Animal Sciences, 26(3), 443-454. https://doi.org/10.5713/ajas. 2012.12365

Lukitaningsih, E., Sulistyo, B., \& Neogrohati, S. (2001). Analysis of polycyclic aromatic hydrocarbons in some meat products. Majalah Farmasi Indonesia, 12(3), 103-108.

Mottram, D. S. (1998). Flavour formation in meat and meat products: a review. Food Chemistry, 62(4), 415-424. https://doi.org/10.1016/S03088146(98)00076-4

Muchenje, V., Hugo, A., Dzama, K., Chimonyo, M., Strydom, P. E., \& Raats, J. G. (2009). Cholesterol levels 
and fatty acid profiles of beef from three cattle breeds raised on natural pasture. Journal of Food Composition and Analysis, 22(4), 354-358. https:// doi.org/10.1016/j.jfca.2008.10.019

Nishimura, T, Liu, A., Hattori, A., \& Takahashi, K. (1998). Changes in mechanical strength of intramuscular connective tissue during postmortem aging of beef. Journal of Animal Science, 76(2), 528-532. https://doi. org/10.2527/1998.762528x

Nishimura, Takanori. (2015). Role of extracellular matrix in development of skeletal muscle and postmortem aging of meat. Meat Science, 109, 48-55. https://doi.org/10.1016/j.meatsci.201 5.05 .015

Otto, K. L., Ferguson, J. D., Fox, D. G., \& Sniffen, C. J. (1991). Relationship between body condition score and composition of ninth to eleventh rib tissue in holstein dairy cows. Journal of Dairy Science, 74(3), 852-859. https://doi.org/10.3168/jds.S0022-030 2(91)78234-9

Rabe, S., Krings, U., \& Berger, R. G. (2003). Influence of oil-in-water emulsion characteristics on initial dynamic flavour release. Journal of the Science of Food and Agriculture, 83(11), 1124-1133. https://doi.org/10.1002/js fa. 1513
Ramalhosa, M., Paula, P., Simone, M., Cristina, D., \& Beatriz, P. O. (2009). Analysis of Polycyclic Aromatic Hydrocarbons In Fish: Evaluation of A Quick, Easy, Cheap, Effective, Rugged \& Safe Extraction Method.

Rey-Salgueiro, L., Martínez-Carballo, E., García-Falcón, M. S., GonzálezBarreiro, C., \& Simal-Gándara, J. (2009). Occurrence of polycyclic aromatic hydrocarbons and their hydroxylated metabolites in infant foods. Food Chemistry, 115(3), 814819. https://doi.org/10.1016/j.foodche m.2008.12.095

Ustuner, H., Yalcintan, H., Orman, A., Ardicli, S., Ekiz, B., Gencoglu, H., \& Kandazoglu, O. (2016). Effects of initial fattening age on carcass characteristics and meat quality in Simmental bulls imported from Austria to Turkey. South African Journal of Animal Science, 47(2), 194-201. https://doi.org/10.4314/saja s.v47i2.11

Whittier, J., Steevens, B., \& Weaver, D. (1993). Body condition scoring of beef and dairy animals. University of Missouri Extention.

Wood, J. D., \& Enser, M. (1997). Factors influencing fatty acids in meat and the role of antioxidants in improving meat quality. British Journal of Nutrition, 78(1), S49-S60. https://doi.org/10.10 79/BJN19970134 